\title{
PENGARUH TATA KELOLA PERUSAHAAN, MANAJEMEN LABA RIIL, DAN KEPEMILIKAN PEMERINTAH TERHADAP KUALITAS LABA PADA PERUSAHAAN DI INDEKS LQ-45
}

\author{
Jeremi Martinus ${ }^{1)}$; Rahayu Kusumawati ${ }^{2)}$ \\ 1).jeremimartinus13@gmail.com, Politeknik Keuangan Negara STAN \\ 2)jesuisayubelle@pknstan.ac.id, Politeknik Keuangan Negara STAN* \\ *email korespondensi
}

\begin{abstract}
The importance of earning information are so crucial in this modern age of businesses, forcing each companies to create a good quality earnings to fullfill the demand from investors. Therefore it requires a good corporate governance to solve the earning management problem within companies to achieve good quality earnings. This study aims to obtain the empirical evidence of the effect of good corporate governance, real earning management, and government ownership on earning quality. The analysis conducted on 23 companies which consistent listed in LQ45 index from 2016 to 2020 was chosen through a purposive sampling method, so that 115 observations were obtained. This study engages a panel data regression model. This study reveals that good corporate governance, which represented by managerial ownership and audit comitee positively affect earning quality, while managerial ownership and independent board of commissioners negatively affect earning quality. For real earning management variable, only cash flow manipulation negatively affect earning quality, while discretionary expense manipulation and production cost manipulation positively affect earning quality. Meanwhile, government ownership has a negative effect on earning quality.
\end{abstract}

Keywords: earning quality, good corporate governance, real earning management, government ownership

\begin{abstract}
Abstrak
Pentingnya informasi laba dalam iklim bisnis di zaman modern seperti ini menuntut setiap perusahaan untuk menghasilkan laba yang berkualitas demi memenuhi keinginan investor. Oleh karena itu, diperlukan tata kelola yang dapat mengatasi permasalahan manajemen laba untuk dapat menghasilkan laba yang berkualitas. Penelitian ini bertujuan untuk mengetahui pengaruh tata kelola perusahaan, manajemen laba riil, dan kepemilikan pemerintah terhadap kualitas laba. Analisis dalam penelitian ini dilakukan terhadap 23 perusahaan yang konsisten berada dalam indeks LQ45 sepanjang periode 2016 hingga 2020 yang dipilih berdasarkan metode purposive sampling, sehingga didapatkan total sebanyak 115 observasi. Penelitian ini menggunakan model regresi data panel. Hasil penelitian menunjukan bahwa variabel tata kelola perusahaan, yang diproksikan oleh kepemilikan manajerial dan komite audit berpengaruh positif sedangkan kepemilikan institusional dan dewan komisaris independen berpengaruh negatif terhadap kualitas laba. Untuk variabel manajemen laba riil, hanya manipulasi arus kas saja yang berpengaruh negatif, sedangkan manipulasi beban diskresioner dan biaya produksi berpengaruh positif terhadap kualitas laba. Sementara itu, kepemilikan pemerintah memiliki pengaruh negatif terhadap kualitas laba. Kata kunci: kepemilikan pemerintah, kualitas laba, manajemen laba riil, tata kelola perusahaan.
\end{abstract}

\section{PENDAHULUAN}

Pesatnya pertumbuhan dan informasi menciptakan iklim bisnis yang makin kompetitif, pelaku bisnis dituntut untuk berusaha semaksimal mungkin demi menjalankan strategi bisnis yang mereka miliki, salah satunya dengan memperoleh informasi yang berkualitas. Dengan memperoleh informasi yang tepat, perusahaan dapat mencapai tujuan yang ingin mereka capai yaitu untuk menghasilkan keuntungan. Salah satu langkah yang selama ini dilakukan oleh perusahaan dalam mempertahankan investor dan krediturnya adalah dengan cara melaporkan laba yang tinggi, diiringi dengan kualitas yang baik, sehingga dapat memberikan tingkat pengembalian yang sesuai dengan ekspektasi kreditur maupun investor. Kualitas laba merupakan sebuah konsep yang menggambarkan kemampuan perusahaan untuk menghasilkan informasi laba perusahaan yang mencerminkan laba yang sebenarnya terjadi di lapangan (Widya, 2017). Laporan keuangan yang menyajikan informasi laba tidak berkualitas dapat mengakibatkan dampak yang fatal bagi perusahaan, bahkan bisa mengakibatkan kebangkrutan bagi perusahaan yang terkait. 


\section{JURNALKU}

Volume 1 No. 4, Desember 2021

Salah satu kasus di Indonesia yang belakangan ini sempat menyita perhatian publik adalah kasus pemalsuan laba pada laporan finansial tahunan PT Garuda Indonesia Tbk Tahun 2018, dimana perusahaan diduga melakukan kecurangan saat melaporkan laba dalam jumlah yang tidak masuk akal. Beberapa skandal yang terjadi di Indonesia mengindikasikan bahwa kualitas informasi laporan finansial, termasuk kualitas laba yang diciptakan oleh perusahaan publik di Indonesia masih belum dapat sepenuhnya dikatakan berkualitas meskipun telat diaudit oleh akuntan publik. Yang menjadi perhatian dalam skandal tersebut adalah keterlibatan manajemen perusahaan dalam tindak kecurangan laporan keuangan yang dilakukan. Apabila pihak internal perusahaan memang sengaja terlibat dan memiliki intensi untuk melakukan kecurangan tersebut demi tujuan tertentu yang bersifat oportunistik, maka yang perlu diperhatikan selain kualitas laba adalah tata kelola perusahaan.

Dari beberapa contoh kasus yang telah disebutkan sebelumnya, dapat disimpulkan bahwa informasi mengenai laba merupakan suatu indikator kinerja yang penting bagi sebuah perusahaan. Salah satu indikator bahwa perusahaan telah mewujudkan laba yang berkualitas adalah tindakan manajemen laba (Nanang dan Tanusdjaja, 2019). Manajemen laba dapat didefinisikan sebagai suatu sikap yang dilakukan manajer perusahaan dalam menata perusahaan via pemilihan strategi untuk menghasilkan informasi keuangan yang diinginkan. Manajemen laba sendiri terbagi menjadi dua, yakni manajemen laba yang bersifat akrual maupun yang bersifat riil. Penelitian yang dilakukan Ningsih (2017) memberikan kesimpulan bahwa manajemen cenderung melakukan manajemen laba secara riil ketimbang akrual karena manajemen laba riil dianggap lebih sulit terdeteksi oleh auditor dan regulator dibandingkan manajemen laba berbasis akrual sebagaimana penelitian yang dilakukan oleh Nugroho dan Firmansyah (2018) berhasil membuktikan bahwa manipulasi aktivitas riil yang dilakukan perseroan manufaktur di Indonesia terkait keputusan operasional tentang produksi, strategi penjualan, dan pemangkasan beban diskresioner kurang mendapat perhatian dari pemeriksa eksternal.

Teori agensi menerangkan bahwa principal dan agen memiliki ketertarikan yang berbeda (Suwardjono, 2011) dimana pemilik cenderung menginginkan agar kinerja perusahaan selalu meningkat sehingga mereka akan mendapatkan tingkat pengembalian yang tinggi atas penanaman modal pada entitas, sedangkan manajemen perusahaan ingin mendapatkan kompensasi yang tinggi atas kinerja yang dilakukannya terhadap perusahaan. Untuk memaksimalkan kualitas laba yang tercermin dalam laporan keuangan dan menghindari adanya konflik keagenan antara manajemen dengan pemilik perusahaan, serta meminimalisir efek samping dari tindakan manajemen laba yang tidak bertanggung jawab, maka diperlukan suatu mekanisme tata kelola yang bermanfaat atau sering disebut sebagai Good Corporate Governance (GCG). Tata kelola dapat dikatakan sebagai salah satu cara untuk mengoptimalkan valuasi perseroan dan meminimalisir terjadinya manipulasi laba yang dapat menumbuhkan kepercayaan pemilik modal terhadap laporan keuangan. Tata kelola yang efektif dan efisien merupakan salah satu penentu utama dalam menjaga pemegang saham untuk tetap menanamkan modalnya di perusahaan. Oleh karena itu, dampak adanya tata kelola perusahaan yang baik di suatu entitas diduga akan berefek pada manipulasi laba dengan kualitas laba. Penelitian yang dilakukan oleh Oktaviani, et al. (2018) menyatakan bahwa tata kelola perusahaan yang diproksikan oleh kepemilikan institusional, kepemilikan manajerial, dewan komisaris independen, dan komite audit berpengaruh signifikan terhadap kualitas laba. Hasil yang berbeda ditunjukan oleh Nanang dan Tanusdjaja (2019), penelitian tersebut menyimpulkan bahwa mekanisme tata kelola perusahaan yang diproksikan dengan kepemilikan institusional, kepemilikan manajerial, komite audit, dan dewan komisaris independen tidak memiliki pengaruh signifikan terhadap kualitas laba. 


\section{JURNALKU}

Volume 1 No. 4, Desember 2021

Permasalahan mengenai kualitas laba yang ada di Indonesia seringkali dikaitkan dengan praktik manajemen laba dan tata kelola yang dimiliki tiap perusahaan. Namun masih jarang penelitian di Indonesia yang menganalisis dampak kepemilikan pemerintah terhadap kualitas laba yang dihasilkan oleh perusahaan di sektor privat maupun sektor publik. Variabel kepemilikan pemerintah telah beberapa kali digunakan pada penelitian di Tiongkok, salah satunya yang dilakukan oleh Zhuang (2017) yang membandingkan kualitas laba perusahaan milik pemerintah dengan swasta, penelitian tersebut menunjukan bahwa entitas milik pemerintah di Tiongkok menghasilkan kualitas laba yang rendah ketimbang milik swasta di tiga sektor industri (manufaktur, properti, dan retail). Kepemilikan pemerintah dapat menjadi variabel yang menarik bagi penelitian tentang kualitas laba milik, hal itu dikarenakan berbagai macam skandal akuntansi di Indonesia terjadi pada perusahaan milik pemerintah atau biasa disebut BUMN. Beberapa kasus yang menimpa BUMN seperti kasus pemalsuan laporan keuangan pada Garuda Indonesia di Tahun 2018 cukup memberi pelajaran bahwa perusahaan milik pemerintah pun tidak luput dari skandal akuntansi akibat aktivitas manajemen laba yang dilakukan manajer sebagai bagian dari tata kelola perusahaan, hal tersebut menunjukan bahwa tata kelola milik BUMN masih belum bisa beroperasi sesuai harapannya.

Berdasarkan beberapa penelitian terdahulu yang telah diuraikan, terdapat beberapa hasil yang berbeda terkait pengaruh tata kelola dan manajemen laba terhadap kualitas laba. Perbedaan hasil tersebut merupakan salah satu alasan yang mendasari mengapa perlu dilakukan konfirmasi lagi bagaimana pengaruh-pengaruh variabel tersebut menggunakan proksi yang serupa terhadap kualitas laba. Selain itu, variabel kepemilikan pemerintah (government ownership) juga merupakan hal yang membedakan penelitian ini dengan penelitian sebelumnya. Variabel kepemilikan pemerintah masih jarang digunakan dalam penelitian mengenai kualitas laba di Indonesia, meski sudah beberapa kali digunakan di penelitian di luar negeri. Beberapa penelitian di mancanegara telah menunjukan bahwa kualitas laba yang dihasilkan oleh perusahaan milik pemerintah (state-owned entities) cenderung lebih rendah dibanding perusahaan swasta dikarenakan adanya perlindungan khusus yang diberikan kepada perusahaan milik pemerintah oleh negara yang bersangkutan. Perbedaan selanjutnya terletak di variabel manajemen laba riil yang pada penelitian ini digunakan sebagai variabel independen, dimana pada beberapa penelitian sebelumnya variabel tersebut seringkali digunakan sebagai variabel dependen. Hal tersebut dikarenakan berdasarkan teori agensi, semakin tinggi manajemen laba yang dilakukan maka semakin rendah kualitas laba yang dihasilkan. Selain itu penelitian ini menggunakan model manajemen laba riil dibandingkan model manajemen laba akrual karena manajemen laba riil dianggap lebih dapat menggambarkan secara nyata aktivitas manajemen laba yang dilakukan oleh para manajer dalam perusahaan (Graham et al., 2005; Roychowdhury, 2006).

Sampel dalam penelitian ini menggunakan perusahaan yang terdaftar dalam indeks LQ45 di Bursa Efek Indonesia karena perusahaan dalam indeks tersebut merupakan perusahaan dengan nilai kapitalisasi pasar yang tinggi, dengan kondisi keuangan yang stabil dari tahun ke tahun, juga memiliki tingkat perdagangan saham dengan nilai dan volume stransaksi yang tinggi sehingga dapat menggambarkan kondisi pasar bursa secara umum. Sampel dalam penelitian ini berbeda dengan penelitian terdahulu dengan topik yang serupa, dimana pada sebagian besar penelitian terdahulu menggunakan perushaan manufaktur sebagai sampelnya. Selain itu, sebagian perusahaan yang terdaftar di indeks LQ45 merupakan perusahaan BUMN, sehingga diharapkan dapat menggambarkan variabel kepemilikan pemerintah dalam penelitian ini. 


\section{JURNALKU}

Volume 1 No. 4, Desember 2021

\section{KAJIAN PUSTAKA}

Teori agensi menyatakan bahwa hubungan yang terjadi pada suatu entitas merupakan nexus of contract, dengan kata lain teori keagenan menjelaskan hubungan antara principal sebagai pemilik sumber daya dan agen sebagai pengelola dan pengendali sumber daya tersebut (Jensen dan Meckling, 1976). Principal merupakan para stakeholder yang menyediakan sumber daya untuk kelanjutan bisnis perusahaan baik itu berasal dari pemilik saham, kreditur, atau Pemerintah. Di sisi lain, dimaksud sebagai agen adalah manajer perusahaan yang diberi kewenangan untuk mengatur aktivitas operasional perusahaan. Principal mempekerjakan para agen untuk melaksanakan tugas tertentu demi memenuhi kepentingan mereka, termasuk mendelegasikan kewenangan untuk mengamcil keputusan (Antoni, 2005).

Teori agensi menyatakan bahwa manajemen memiliki informasi yang lebih lengkap mengenai perusahaan ketimbang pemilik. Hal ini dikarenakan principal tidak dapat mengawasi aktivitas operasional secara berkala. Kondisi tersebut merupakan suatu fenomenya yang disebut sebagai asymmetric information. Godfrey et al. (2010, 362) menyatakan alasan lain yang menyebabkan masalah keagenan yaitu karena baik principal dan agen sama-sama memiliki keinginan untuk memaksimalkan keuntungan masing-masing yang memotivasi agen untuk bertindak tidak selaras dengan keinginan principal. Teori ini juga menyatakan bahwa perselisihan antara principal dengan agen dapat diminimalisir dengan mekanisme pengawasan yang optimal. Machfoedz (2003) menyatakan bahwa perlakuan manipulatif oleh manajer berawal dari konflik kepentingan dapat dicegah melalui mekanisme pengawasan untuk memadankan perbedaan kepentingan yang ada, yaitu melalui kepemilikan saham oleh pihak manajer dan investor institusi, serta pengawasan dari dewan komisaris dan komite audit.

Penelitian yang dilakukan Domash (2009) menjelaskan bahwa kepemilikan manajerial merupakan para manajer perusahaan yang juga ikut serta berperan sebagai pemegang saham dalam perusahaan tersebut, dimana mereka ikut aktif dalam proses pengambilan keputusan pada suatu perusahaan yang bersangkutan, yang dinyatakan dengan tingkat kepemilikan saham perusahaan oleh manajer perusahaan. Penelitian yang dilakukan oleh Oktaviani, et al. (2015) yang menguji pengaruh mekanisme tata kelola perusahaan terhadap kualitas laba menyimpulkan bahwa kepemilikan manajerial memiliki pengaruh positif terhadap kualitas laba. Kepemilikan manajerial secara umum dipercaya dapat meminimalkan konflik keagenan yang berasal dari perbedaan kepentingan antara manajemen perusahaan dengan pemilik perusahaan, hal ini dikarenakan manajer selain berperan sebagai pengelola perusahaan, juga berperan sebagai memiliki pemilik saham perusahaan sehingga akan berusaha untuk memajukan perusahaan karena manajer merupakan pemilik dari perusahaan.

H1.1 = Kepemilikan manajerial berpengaruh positif terhadap kualitas laba.

Kepemilikan institusional merupakan saham yang dimiliki oleh investor institusional seperti bank, perusahaan asuransi, dana pensiunan dan investment banking (Hanafi, 2003). Kepemilikan Institusional dalam suatu perusahaan dapat mengatasi masalah konflik keagenan melalui pengawasan terhadap manajemen dalam meningkatkan kinerjanya untuk menghasilkan laba yang berkualitas (Darabali dan Saitri, 2016). Penelitian yang dilakukan oleh Darabali dan Saitri (2016) dan Budianto (2018) yang menguji faktor-faktor yang mempengaruhi kualitas laba menunjukan bahwa kepemilikan institusional memiliki pengaruh positif terhadap kualitas laba. Kepemilikan institusional dalam porsi besar dapat memberikan pengawasan secara masif terhadap tindakan manajemen sehingga dapat meminimalisir tindakan oportunistik oleh pihak manajemen.

$\mathbf{H}_{1.2}=$ Kepemilikan institusional berpengaruh positif terhadap kualitas laba.

Dewan komisaris independen menggambarkan pihak netral yang tidak memiliki kepentingan dalam perusahaan untuk menjaga kontrol dalam pengendalian operasi bisnis. Peran pengawasan dari dewan komisaris independen ini diharapkan akan meminimalisir konflik 


\section{JURNALKU}

Volume 1 No. 4, Desember 2021

keagenan yang timbul antara dewan direksi dengan pemegang saham. Penelitian oleh Oktaviani, et al. (2015) dan Wayan \& Ayu, (2019) yang menguji pengaruh mekanisme tata kelola perusahaan terhadap kualitas laba menemukan bukti bahwa dewan komisaris independen mempunyai pengaruh yang positif terhadap kualitas laba. Karakteristik dewan komisaris secara umum dan khususnya komposisi dewan komisaris independen dapat menjadi suatu mekanisme yang menentukan tindakan manajemen laba yang dapat mempengaruhi kualitas laba.

$\mathbf{H}_{\mathbf{1 . 3}}$ = Dewan komisaris independen berpengaruh positif terhadap kualitas laba.

Komite audit bertanggungjawab untuk mengawasi laporan keuangan, mengawasi audit eksternal, dan mengawasi sistem pengendalian internal. Keberadaan komite audit diharapkan dapat mengurangi sifat oportunistik manajemen terkait masalah keagenan dengan mengawasi laporan keuangan dan melakukan pengawasan pada audit eksternal (Budianto, 2018). Penelitian yang dilakukan oleh Puspitawati et al. (2019) dan Putri \& Fitriasari (2017) yang menguji pengaruh mekanisme tata kelola perusahaan terhadap kualitas laba menunjukan bahwa keberadaan komite audit memberikan pengaruh positif terhadap kualitas laba yang dilaporkan. Hal ini menunjukan bahwa keberadaan komite audit dapat memberikan pengawasan terhadap pelaksanaan bisnis perusahaan sehingga perusahaan dapat menghasilkan laporan keuangan dengan kualitas laba yang tinggi, selain itu komite audit juga dapat meningkatkan efektifitas dan efisiensi pengendalian internal sehingga dapat mengurangi resiko tindakan oportunistik oleh manajemen.

$\mathbf{H}_{1.4}=$ Komite audit berpengaruh positif terhadap kualitas laba.

Berdasarkan teori agensi, terdapat suatu ketidakseimbangan informasi antara agen dengan principal, yang dikenal sebagai asymmetric information, yang melatarbelakangi terjadinya konflik agensi. Ketidakseimbangan informasi tersebut dapat dimanfaatkan oleh agen, yaitu manajer perusahaan yang memiliki informasi lebih banyak mengenai perusahaan ketimbang principal, untuk melakukan manajemen laba demi meraih keuntungannya pribadi. Survei menunjukkan bahwa manajer perusahaan cenderung lebih memilih manajemen laba riil daripada manajemen laba berbasis akrual untuk mencapai target (Graham et al., 2005). Beberapa penelitian terdahulu juga telah menggunakan variabel manajemen laba riil sebagai alat ukur manajemen laba. Salah satunya dilakukan oleh Vajriyanti et al. (2019) yang mengukur manajemen laba riil hanya dengan menggunakan manipulasi arus kas, penelitian tersebut membuktikan bahwa manajemen laba riil memiliki pengaruh negatif terhadap nilai perusahaan. Hasil penelitian tersebut sejalan dengan penelitian penelitian (Deva \& Machdar, 2017) yang mengukur manajemen laba riil melalui manipulasi arus kas, beban diskresioner, dan biaya produksi.

H2.1= Manajemen laba riil melalui manipulasi arus kas operasi berpengaruh negatif terhadap kualitas laba

$\mathbf{H}_{2.2}=$ Manajemen laba riil melalui penurunan beban diskresionari berpengaruh negatif terhadap kualitas laba

$\mathbf{H}_{2.3}=$ Manajemen laba riil melalui manipulasi produksi berpengaruh negatif terhadap kualitas laba

Teori keagenan dapat menjelaskan fenomena masalah keagenan di Indonesia khususnya dalam struktur kepemilikan. Sesuai dengan teori keagenan bahwa kinerja perusahaan dapat menurun akibat masalah yang terjadi antara manajer dan pemegang saham (conflict of interest). Struktur kepemilikan oleh beberapa peneliti dipercaya mampu mempengaruhi jalannya perusahaan yang pada akhirnya berpengaruh pada kinerja perusahaan dalam mencapai tujuan perusahaan yaitu memaksimalkan nilai perusahaan (Wiranata dan Nugrahanti, 2013). Sejalan dengan teori tersebut, beberapa penelitian terdahulu tentang kualitas laba membuktikan bahwa kualitas laba yang dihasilkan oleh suatu perusahaan dipengaruhi oleh kepemilikan pemerintah dari negara tempat perusahaan itu menjalankan bisnisnya. Beberapa penelitian menjelaskan 


\section{JURNALKU}

Volume 1 No. 4, Desember 2021

bagaimana perusahaan milik pemerintah menghasilkan kualitas laba yang lebih rendah ketimbang perusahaan milik swasta. Hal tersebut dikarenakan adanya inefisiensi dan campur tangan pemerintah dalam proses bisnis yang lebih mengutamakan pelayanan terhadap masyarakat ketimbang menghasilkan laba. Kesamaan hasil penelitian terdahulu diperoleh meskipun menggunakan lebih dari satu negara sebagai objek penelitiannya, seperti Tiongkok dan Indonesia (Chan, 2016; Ding et al., 2007; Zhuang, 2017).

$\mathbf{H}_{3}=$ Kepemilikan pemerintah berpengaruh negatif terhadap kualitas laba

\section{METODE}

Penelitian ini menggunakan data sekunder dimana sumber sekunder dalam penelitian ini berupa laporan keuangan ataupun laporan tahunan perusahaan yang terdaftar pada Bursa Efek Indonesia dalam kurun waktu tahun 2016 hingga tahun 2020. Dalam penelitian ini populasi meliputi seluruh perusahan yang terdaftar di indeks LQ45. indeks LQ45 dipilih sebagai populasi karena perusahaan yang terdaftar di indeks tersebut merupakan perusahaan dengan kapitalisasi pasar yang tinggi dalam satu periode, kondisi keuangan yang stabil dan sudah lama memperdagangkan sahamnya di Bursa Efek Indonesia, sehingga diharapkan dapat memberikan gambaran secara umum mengenai kondisi ideal dari transaksi di bursa efek. Dalam penelitian ini, sampel diambil secara nonprobablity sampling dengan teknik purposive sampling, yaitu teknik penentuan sampel dengan pertimbangan tertentu (Sugiyono, 2016). Kriteria tersebut adalah sebagai berikut: (1) Perusahaan telah terdaftar di Bursa Efek Indonesia dan termasuk ke dalam indeks LQ45; (2) Perusahaan tersebut termasuk dalam indeks LQ45 minimal sepanjang empat tahun berturut-turut atau yang konsisten selama lima tahun berturutturut dari 2016 hingga 2020; (3) Perusahaan mempunyai informasi yang dibutuhkan dengan jelas dalam laporan tahunannya untuk periode 2014-2020; (4) Perusahaan mengeluarkan laporan keuangan tahunan yang menggunakan mata uang rupiah sebagai mata uang pelaporannya. Hal ini bertujuan agar seluruh data dapat diproses dengan metode yang seragam sehingga menghasikan informasi yang dapat diandalkan; dan (5) Perusahaan tersebut bukan termasuk perusahaan di sektor keuangan. Hal ini dikarenakan perbedaan format laporan keuangan pada perusahaan sektor keuangan yang beresiko mendistorsikan pengukuran variabel kualitas laba.

Berdasarkan kriteria tersebut, maka penulis dapat memberikan gambaran terkait penentuan sampel penelitian seperti yang tercantum pada tabel 1 berikut ini:

\begin{tabular}{llc} 
No. & Tabel 1. Kriteria dan jumlah perusahaan yang digunakan dalam sampel \\
Kriteria & \multicolumn{1}{c}{$\begin{array}{c}\text { Jumlah } \\
\text { Perusahaan }\end{array}$} \\
\hline 1 & $\begin{array}{l}\text { Perusahaan dalam indeks LQ-45 yang terdaftar di Bursa Efek } \\
\text { Indonesia }\end{array}$ & 45 \\
\hline 2 & $\begin{array}{l}\text { Perusahaan terdaftar dalam indeks LQ-45 dan konsisten pada } \\
\text { periode 2016-2020 }\end{array}$ & 28 \\
\hline $3 \quad \begin{array}{l}\text { Perusahaan memiliki informasi yang dibutuhkan dengan } \\
\text { lengkap }\end{array}$ & 28 \\
\hline $4 \quad \begin{array}{l}\text { Perusahaan menerbitkan laporan keuangan tahuan dengan } \\
\text { mata uang rupiah }\end{array}$ & 25 \\
\hline $5 \quad$ Perusahaan yang tidak bergerak disektor keuangan & 23 \\
\hline Jumlah sampel perusahaan & 23 \\
\hline Periode (tahun) & $\mathbf{1 1 5}$
\end{tabular}

Sumber: Bursa Efek Indonesia yang diolah kembali oleh penulis 


\section{JURNALKU}

Volume 1 No. 4, Desember 2021

Berdasarkan penjelasan yang telah diberikan, maka model penelitian utama yang akan digunakan adalah dengan persamaan sebagai berikut:

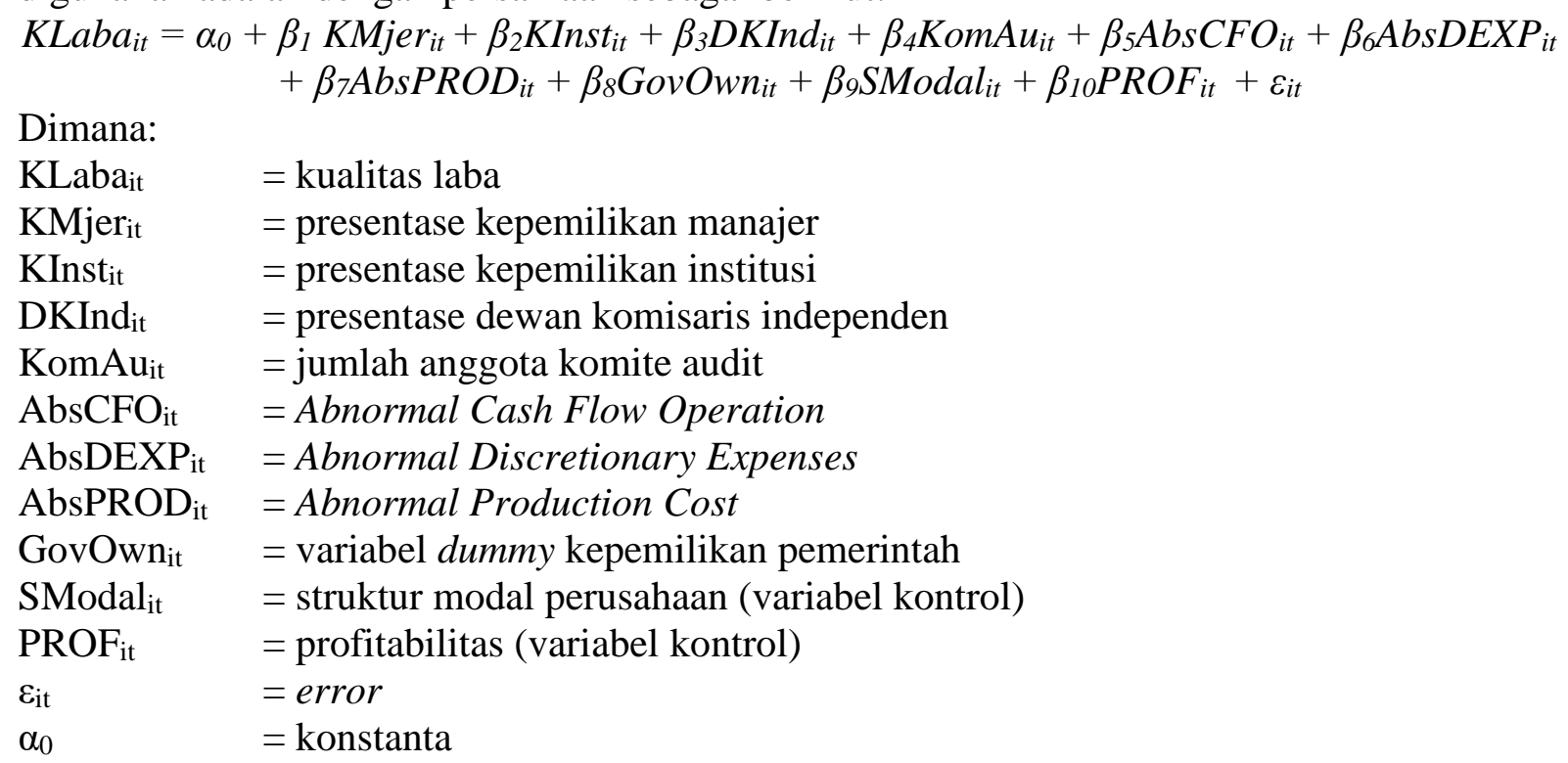

\section{Operasionalisasi Variabel dan Pengukuran Variabel}

Variabel dependen yang digunakan pada penelitian ini adalah kualitas laba. Kualitas laba pada penelitian ini diukur dengan menggunakan discretionary accrual. Hal itu dikarenakan discretionary accrual merupakan nilai akrual yang timbul dari diskresi/ keleluasaan yang dimiliki oleh manajemen untuk memilih metode, prinsip dan estimasi akuntansi. Discretionary accrual yang merupakan hasil dari diskresi manajemen lebih dapat menggambarkan kualitas laba yang dihasilkan ketimbang total accrual maupun non-discretionary accrual, karena kualitas laba sangat dipengaruhi oleh kebijakan ataupun diskresi manajemen atas pelaporan keuangan perusahaan. Variabel kualitas laba yang digunakan pada penelitian ini diukur menggunakan proksi discretionary accrual Jones Model (1991) yang telah dimodifikasi lagi oleh Kasznik (1999). Dalam modelnya, Kasznik menambahkan variabel perubahan cash flow from operations sebagai variabel penjelas. Hal ini dikarenakan Dechow (1994) menemukan bahwa variabel tersebut berpengaruh negatif dengan total akrual. Discretionary accrual model Kasznik dihitung dengan rumus sebagai berikut:

Keterangan:

$$
T A_{i t}=\alpha_{0}+\beta_{1}\left(\Delta R E V_{i t}-\Delta R E C_{i t}\right)+\beta_{2} P P E_{i t}+\beta_{3} \Delta C F O_{i t}+\varepsilon_{i t}
$$

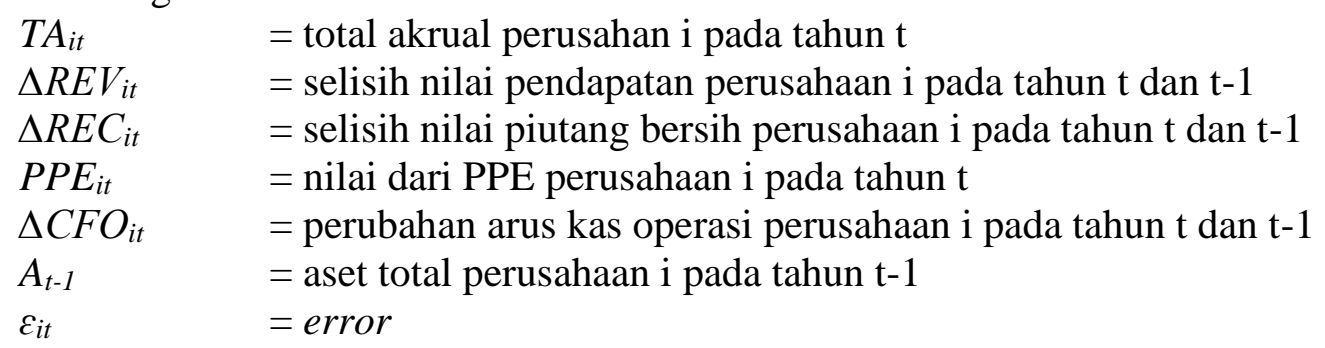

Total akrual secara umum merupakan selisih antara total laba dengan arus kas perusahaan, dimana hal tersebut merupakan estimasi dan penilaian manajemen atas seluruh kejadian akrual yang terjadi. Sedangkan non-discretionary accrual merupakan bagian dari total akrual, yang menggambarkan perubahan akrual yang terjadi tanpa adanya pertimbangan ataupun kebijakan dari manajemen. Nilai discretionary accruals diperoleh dari selisih total akrual dengan non-discretionary accruals. Discretionary accrual yang digunakan pada penelitian ini nilainya diabsolutkan karena sifat dari manipulasi laba itu sendiri dapat mengarah ke nilai akrual yang positif ataupun negatif (Bergstresser \& Philippon, 2006). Manajemen laba, 


\section{JURNALKU}

Volume 1 No. 4, Desember 2021

baik itu yang meningkatkan maupun menurunkan jumlah laba yang dilaporkan akan menurunkan kualitas laba suatu perusahaan (Meniccuci, 2020).

Terdapat tiga variabel independen yang digunakan dalam penelitian ini yaitu tata kelola perusahaan, manajemen laba riil, dan kepemilikan pemerintah. Untuk variabel tata kelola perusahaan, penelitian ini merujuk pada Nanang dan Tanusdjaja (2019) yang mengukur tata kelola perusahaan melalui empat variabel, yaitu kepemilikan manjerial, kepemilikan institusional, dewan komisaris independen, dan komite audit.

\section{Persentase kepemilikan manajerial}

Penelitian ini mengukur tingkat kepemilikan manajerial dengan cara menghitung persentase (\%) total jumlah saham yang dimilki oleh pihak manajemen, yaitu dewan komisaris dan direksi dibagi dengan total jumlah lembar saham yang beredar sebagaimana dirumuskan pada penelitian (Nanang dan Tanusdjaja (2019).

$$
\text { Kepemilikan Manajerial }=\frac{\text { jumlah saham yang dimiliki manajemen }}{\text { jumlah saham yang beredar }} \times 100 \%
$$

Pemilihan proksi ini berdasarkan pernyataan bahwa tata kelola perusahaan akan semakin berkualitas oleh karena pengawasan yang optimal, dimana pengawasan yang optimal tersebut salah satunya diukur dengan persentase kepemilikan manajerial (Nanang dan Tanusdjaja, 2019; Nugroho dan Firmansyah, 2018). Proksi ini juga dipilih karena telah digunakan di berbagai macam penelitian sebelumnnya dengan topik yang serupa dimana hasil dari beberapa penelitian terdahulu tersebut sejalan dengan hipotesis yang digunakan pada penelitian ini (Oktaviani et al., 2015).

\section{Persentase kepemilikan institusional}

Penelitian ini mengukur kepemilikan institusional dengan cara menghitung persentase jumlah lembar saham yang dimiliki oleh investor institusional dibagi dengan jumlah lembar saham yang beredar sebagaimana dilakukan pada penelitian Nanang dan Tanusdjaja (2019). Investor institusional mencakup bank, dana pensiun, perusahaan asuransi, perseroan terbatas, dan lembaga keuangan lainnya. Nanang dan Tanusdjaja (2019).

$$
\text { Kepemilikan Institusional }=\frac{\text { jumlah saham yang dimiliki institusi }}{\text { jumlah saham yang beredar }} \times 100 \%
$$

Pemilihan proksi ini berdasarkan pernyataan bahwa tata kelola perusahaan akan semakin berkualitas oleh karena pengawasan yang optimal, dimana pengawasan yang optimal tersebut salah satunya diukur dengan persentase kepemilikan institusional (Nanang dan Tanusdjaja, 2019; Nugroho dan Firmansyah, 2018). Proksi ini juga dipilih karena telah digunakan di berbagai macam penelitian sebelumnya dengan topik yang serupa dimana hasil dari beberapa penelitian terdahulu tersebut sejalan dengan hipotesis yang digunakan pada penelitian ini (Oktaviani et al., 2015).

\section{Persentase anggota dewan komisaris independen}

Penelitian ini mengukur total persentase dewan komisaris independen dengan membagi jumlah dewan komisaris independen dengan jumlah total dewan komisaris sebagaimana dilakukan pada penelitian Oktaviani, et al. (2015).

$$
\text { Dewan Komisaris Independen }=\frac{\text { jumlah dewan komisaris independen }}{\text { jumlah seluruh dewan komisaris }} \times 100 \%
$$

Pemilihan proksi ini berdasarkan pernyataan bahwa tata kelola perusahaan akan semakin berkualitas oleh karena pengawasan yang optimal, dimana pengawasan yang optimal tersebut salah satunya diukur dengan persentase dewan komisaris independen. Proksi ini juga dipilih karena telah digunakan di berbagai macam penelitian sebelumnnya dengan topik yang serupa dimana hasil dari beberapa penelitian terdahulu tersebut sejalan dengan hipotesis yang digunakan pada penelitian ini (Oktaviani et al., 2015). 


\section{JURNALKU}

Volume 1 No. 4, Desember 2021

\section{Komite audit}

Variabel komite audit diukur dengan menghitung total seluruh anggota komite audit yang dimiliki oleh perusahaan. Proksi yang digunakan untuk mengukur ukuran komite audit didasarkan pada penelitian Nugroho dan Firmansyah (2018) yang menghitung total komite audit yang tercantum pada laporan tata kelola perusahaan.

\section{$K A=\Sigma$ Komite Audit Perusahaan}

Pemilihan proksi ini berdasarkan pernyataan bahwa tata kelola perusahaan akan semakin berkualitas oleh karena pengawasan yang optimal, dimana pengawasan yang optimal tersebut salah satunya diukur dengan total komite audit pada perusahaan. Proksi ini juga dipilih karena telah digunakan di berbagai macam penelitian sebelumnnya dengan topik yang serupa dimana hasil dari beberapa penelitian terdahulu tersebut sejalan dengan hipotesis yang digunakan pada penelitian ini (Oktaviani et al., 2015).

Manajemen laba yang digunakan pada penelitian ini diukur menggunakan pendekatan manajemen laba riil sebagaimana dilakukan pada penelitian Nugroho dan Firmansyah (2018). Penggunaaan proksi manajemen laba riil dilakukan berdasarkan pada hasil beberapa penelitian empiris yang menyimpulkan bahwa manajemen perusahaan cenderung lebih memilih manajemen laba riil ketimbang akrual untuk mencapai targetnya dikarenakan manajemen laba riil dapat memanipulasi aktivitas riil yang dapat lebih diandalkan ketimbang aktivitas akrual (Roychowdhury, 2006). Adapun pendekatan penelitian ini menggunakan tiga jenis pendekatan pada manajemen laba riil, meliputi abnormal cash flow operation, abnormal discretionary expenses, dan abnormal production costs.

\section{Abnormal Cash Flow Operation}

Keterangan:

$$
C F O_{i t} / A_{t-1}=\alpha_{0}+\alpha_{1}\left(1 / A_{t-1}\right)+\alpha_{2}\left(S_{t} / A_{t-1}\right)+\alpha_{3}\left(\Delta S_{t} / A_{t-1}\right)+\varepsilon_{i t}
$$

$C F O_{i t}=$ Arus kas operasi perusahaan i pada tahun $\mathrm{t}$

$A_{t-1} \quad=$ Total aset perusahaan i pada tahun $\mathrm{t}-1$

$S_{i t} \quad=$ Total penjualan perusahaan i pada tahun $\mathrm{t}-1$

$\varepsilon_{\mathrm{it}} \quad=$ Discretionary permanent differences

Abnormal $C F O$ adalah $C F O$ aktual perusahaan dikurangi normal $C F O$ yang dihitung dari perhitungan di atas. Model ini akan diestimasi setiap tahun. Residual dari hasil estimasi merupakan abnormal CFO perusahaan i pada tahun t.

Abnormal Discretionary Expenses

$$
\operatorname{DISEXP}{ }_{i t} / A_{t-1}=\alpha_{0}+\alpha_{1}\left(1 / A_{t-1}\right)+\alpha_{2}\left(S_{t-1} / A_{t-1}\right)+\varepsilon_{i t}
$$

Keterangan:

DISEXP $_{\text {it }}=$ Total beban diskresioner (beban penelitian dan pengembangan, beban iklan, beban penjualan, dan lainnya)

$A_{t-1} \quad=$ Total aset perusahaan i pada tahun $\mathrm{t}-1$

$S_{i t} \quad=$ Total penjualan perusahaan i pada tahun $\mathrm{t}-1$

Normal discretionary expenses disajikan sebagai fungsi linear atas penjualan. Abnormal discretionary expenses merupakan biaya diskresioner aktual dikurangi normal discretionary expenses. DISEXP it adalah discretionary expenses yaitu penjumlahan beban penelitian dan pengembangan, beban iklan, beban penjualan, administrasi, dan umum. Model ini akan akan diestimasi setiap tahun. Residual dari hasil estimasi merupakan abnormal DISEXP perusahaan i pada tahun $\mathrm{t}$. 


\section{JURNALKU}

Volume 1 No. 4, Desember 2021

\section{Abnormal Production Cost}

$$
P R O D_{i t} / A_{t-1}=\alpha_{0}+\alpha_{1}\left(1 / A_{t-1}\right)+\alpha_{2}\left(S_{t} / A_{t-1}\right)+\alpha_{3}\left(\Delta S_{t} / A_{t-1}\right)+\alpha_{4}\left(\Delta S_{t-1} / A_{t-1}\right)+\varepsilon_{i t}
$$

Keterangan:

PROD $_{\text {it }}=$ Penjumlahan harga pokok penjualan dan perubahan persediaan

$A_{t-1} \quad=$ Aset total perusahaan i pada tahun t-1

$S_{i t} \quad=$ Total penjualan perusahaan i pada tahun $\mathrm{t}-1$

$\Delta S t=$ Selisih penjualan perusahaan pada tahun $\mathrm{t}$ dibandingkan akhir tahun $\mathrm{t}-1$

$\Delta S t-1=$ Selisih penjualan perusahaan pada tahun $\mathrm{t}-1$ dibandingkan akhir tahun $\mathrm{t}-2$

Untuk mendapatkan abnormal production costs, dibutuhkan Cost of Goods Sold (COGS) dan perubahan persediaan dalam satu tahun. Dengan menggunakan formula cost of goods sold dan perubahan persediaan, biaya produksi (Prod) didapat dengan penjumlahan keduanya. Abnormal production cost merupakan biaya produksi aktual dikurangi normal production cost. PROD $_{\text {it }}$ merupakan production costs yaitu total akumulasi harga pokok penjualan dan perubahan persediaan. Model ini akan akan diestimasi setiap tahun. Residual dari hasil estimasi merupakan abnormal DISEXP perusahaan i pada tahun $t$.

Penelitian ini mengukur kepemilikan pemerintah dengan variabel dummy, dengan nilai 1 untuk BUMN dan 0 untuk perusahaan swasta yang memenuhi kriteria pemilihan sampel sebagaimana dilakukan pada penelitian Chan (2016). Pengukuran tersebut didasarkan pada aturan yang menyatakan bahwa apabila dalam suatu perusahaan, sebagian besar sahamnya atau minimal 51 persen sahamnya dikuasai oleh pemerintah, maka perusahaan tersebut merupakan Badan Usaha Milik Negara (BUMN).

Penelitian ini menggunakan dua variabel kontrol sebagai berikut.

Penelitian ini mengukur struktur modal dengan proksi debt-to-quity ratio (DER) yang diukur dengan cara membagi total kewajiban dengan total modal suatu perusahaan selama satu periode. Pemilihan proksi tersebut berdasarkan pada penelitian empiris oleh Anggrainy dan Priyadi (2019).

\section{$\mathrm{DER}=($ total liabilitas $) /($ total ekuitas $)$}

Penelitian ini mengukur profitabilitas dengan proksi return-on-asset (ROA) yang diukur dengan membagi total net income dengan jumlah aset yang dimiliki suatu perusahaan pada periode tertentu. Pemilihan proksi tersebut didasarkan pada penelitian terdahulu yang dilakukan oleh Laoli dan Herawaty (2019).

$$
\mathrm{ROA}=(\text { laba bersih }) /(\text { total asset })
$$

\section{HASIL DAN PEMBAHASAN}

Tabel 2 menunjukkan hasil ringkasan statistik deskriptif variabel penelitian.

Tabel 1. Hasil Statistik Deskriptif

\begin{tabular}{lllllll} 
Variabel & total & Mean & Median & Std. Dev. & Min & Max \\
\hline Klaba & 115 & 0.036074 & 0.02349 & 0.033208 & 0.000639 & 0.15991 \\
\hline KMjer & 115 & 0.112204 & 0.01473 & 0.214515 & 0 & 0.97 \\
\hline KInst & 115 & 96.19305 & 97.59 & 3.735728 & 83.99 & 99.815 \\
\hline DKInd & 115 & 39.82643 & 37.5 & 11.78031 & 16.6666 & 83.333 \\
\hline KomAu & 115 & 3.460870 & 3 & 0.740874 & 3 & 7 \\
\hline AbsCFO & 115 & 0.143645 & 0.10755 & 0.113162 & -0.01723 & 0.57378 \\
\hline AbsDEXP & 115 & 0.161128 & 0.13759 & 0.137662 & -0.08172 & 0.76049 \\
\hline AbsPROD & 115 & 0.596286 & 0.51654 & 0.373692 & -0.03060 & 1.67091 \\
\hline GovOwn & 115 & 0.347826 & 0 & 0.478365 & 0 & 1 \\
\hline SModal & 115 & 1.188808 & 0.73662 & 1.281430 & 0.153484 & 9.87399 \\
\hline PROF & 115 & 0.108904 & 0.08611 & 0.103478 & -0.13818 & 0.46660
\end{tabular}

Sumber: diolah dari aplikasi Stata 14 


\section{JURNALKU}

Volume 1 No. 4, Desember 2021

Selanjutnya, pengujian dilakukan dengan menggunakan data panel, dengan common effect model (CEM). Adapun ringkasan hasil uji hipotesis adalah sebagai berikut.

Tabel 3. Hasil Uji-t (Uji Signifikansi Parsial)

\begin{tabular}{lllll}
\hline Variabel & Hipotesis & Coefficient & Prob. & Signifikansi \\
\hline Cons & & 0.0940716 & 0.0005 & \\
\hline KMjer & + & 0.0116457 & 0.1925 & Tidak signifikan \\
\hline KInst & + & -0.000891 & 0.0000 & signifikan \\
\hline DKInd & + & -0.001933 & 0.0000 & signifikan \\
\hline KomAu & + & 0.0085077 & 0.0265 & signifikan \\
\hline AbsCFO & - & -0.054409 & 0.1705 & Tidak signifikan \\
\hline AbsDEXP & - & 0.0482235 & 0.0475 & signifikan \\
\hline AbsPROD & - & 0.0349961 & 0.0020 & signifikan \\
\hline GovOwn & - & -0.004602 & 0.2750 & Tidak signifikan \\
\hline SModal & & 0.0027085 & 0.1575 & \\
\hline PROF & & 0.1492074 & 0.0070 & \\
\hline
\end{tabular}

Sumber: Diolah dari aplikasi stata 14

\section{HASIL DAN PEMBAHASAN}

\section{Pengaruh kepemilikan manajerial terhadap kualitas laba}

Berdasarkan hasil pengujian hipotesis, dapat diketahui bahwa variabel kepemilikan manajerial memiliki pengaruh positif terhadap kualitas laba. Pengaruh positif tersebut mengartikan bahwa kepemilikan saham oleh manajer merupakan salah satu cara yang dapat dilakukan untuk mengatasi konflik agensi antara pemilik saham dengan manajer perusahaan (Sulaeman, 2020). Teori agensi menjelaskan hubungan antara manajer dengan pemilik saham sebagai nexus of contract (Puspitawati et al., 2019). Dalam hubungan tersebut, masing-masing pihak tentu cenderung untuk memaksimalkan tujuan pribadi mereka. Masalah akan muncul ketika manajer perusahaan dan pemilik saham memiliki tujuan yang berbeda. Sebagai pihak yang lebih diunggulkan berkat adanya asymmetric information, manajer perusahaan cenderung memanfaatkan kesempatan tersebut untuk memanipulasi kinerja perusahaan sehingga seolaholah perusahaan telah menghasilkan keuntungan yang diinginkan.

Untuk mengatasi permasalahan tersebut, maka salah satu cara yang dapat dilakukan adalah dengan menempatkan para manajer sebagai pemilik saham, sehingga dapat mengurangi dampak dari perbedaan kepentingan antara pemilik saham dengan manajer perusahaan (Oktaviani et al., 2015). Dengan menempatkan manajer perusahaan sebagai salah satu pemilik saham perusahaan, mereka tidak hanya akan berfokus untuk memaksimalkan tingkat bonus ataupun insentif lainnya, namun juga akan berusaha untuk meningkatkan harga saham yang mereka miliki. Dengan adanya kepemilikan saham oleh manajer perusahaan, maka manajer tersebut akan ikut merasakan dampak dari proses pengambilan keputusan yang dilakukan oleh manajer perusahaan, sehingga mereka cenderung ingin menghasilkan kinerja dan laba yang berkualitas yang bukan hanya menghasilkan tingkat pengembalian yang sesuai dengan harapan para pemilik saham, namun juga kepada manajer tersebut.

\section{Pengaruh kepemilikan institusional terhadap kualitas laba}

Berdasarkan hasil pengujian hipotesis, dapat diketahui bahwa variabel kepemilikan institusional berpengaruh negatif terhadap kualitas laba. Hasil penelitian tidak sesuai dengan hipotesis penelitian yang menyatakan bahwa kepemilikan institusional memiliki pengaruh positif terhadap kualitas laba.

Hal ini dapat dijelaskan dari perspektif investor institusi, dimana keberadaan mereka dalam melakukan pengawasan terhadap perilaku manajer dinilai belum cukup efektif untuk memotivasi manajer untuk menghasilkan laba yang berkualitas bagi perusahaan (Kristiani et 


\section{JURNALKU}

Volume 1 No. 4, Desember 2021

al., 2014). Pengawasan yang kurang efektif inilah yang mengakibatkan manajer dapat memanfaatkan kesempatan tersebut untuk melakukan tindakan oportunistik yang berdampak negatif bagi kualitas laba perusahaan. Selain itu, pengawasan dari investor institusi yang kurang efektif dapat terjadi karena kurangnya regulasi dan dasar hukum tata kelola perusahaan yang mengakibatkan buruknya kualitas tata kelola sehingga berdampak pada kualitas laba yang dihasilkan.

Selain disebabkan oleh rendahnya tingkat pengawasan yang dilakukan investor institusi terhadap manajer perusahaan, penyebab hubungan negatif antara kepemilikan institusional dengan kualitas laba dapat terjadi karena adanya penelitian terdahulu yang menyatakan bahwa investor institusi cenderung memfokuskan pada current earnings ketimbang kinerja perusahaan dalam jangka panjang (Cheng et al., 2011; Ujiyantho \& Pramuka, 2007).

Pengaruh dewan komisaris independen terhadap kualitas laba

Berdasarkan hasil pengujian hipotesis, dapat diketahui bahwa variabel dewan komisaris independen berpengaruh negatif terhadap kualitas laba. Hasil penelitian ini tidak sesuai dengan hipotesis penelitian yang menyatakan bahwa dewan komisaris independen memiliki pengaruh positif terhadap kualitas laba.

Hal tersebut dapat dijelaskan dari sudut pandang dewan komisaris independen itu sendiri. Dewan komisaris independen tidak selamanya memberikan pengawasan secara menyeluruh terhadap kinerja manajer, terkadang keberadaan komisaris independen merupakan memenuhi regulasi yang berlaku saja (Boediono, 2005; Ujiyantho \& Pramuka, 2007). Keputusan Ketua BAPEPAM Nomor: Kep-29/PM/2004 menetapkan bahwa setiap perusahaan yang terdaftar di Bursa Efek Indonesia wajib memiliki komisaris independen, apabila keberadaan dewan komisaris independen hanya berfungsi sebagai formalitas saja, maka dikhawatirkan dewan komisaris independen tersebut tidak akan menambah nilai dan menegakan good corporate governance dalam perusahaan.

Proporsi dewan komisaris independen sebagai bagian dari tata kelola perusahaan yang terbukti memberikan dampak negatif terhadap kualitas laba pada penelitian ini menunjukan bahwa jumlah dan proporsi dewan komisaris independen yang dimiliki sebuah perusahaan belum tentu menjadi jaminan efektivitas pengawasan terhadap kinerja manajemen perusahaan. Akan tetapi, terdapat faktor lain yang dapat memberikan dampak positif terhadap efektivitas fungsi pengawasan oleh dewan komisaris independen yaitu nilai, norma, dan kepercayaan yang dimiliki suatu perusahaan (M. M. Jennings, 2005).

Pengaruh komite audit terhadap kualitas laba

Berdasarkan hasil pengujian hipotesis, dapat diketahui bahwa variabel komite audit berpengaruh positif terhadap kualitas laba. Hasil penelitian yang menunjukan bahwa komite audit memiliki pengaruh positif, hal ini sesuai dengan hipotesis penelitian yang menyatakan bahwa komite audit berpengaruh positif terhadap kualitas laba.

Pengaruh positif tersebut dapat diartikan bahwa keberadaan komite audit dalam sebuah perusahaan terbukti telah menjalankan fungsi dan tanggung jawab dengan semestinya dalam melakukan pengawasan terhadap manajer perusahaan dalam rangka mencegah ataupun menghambat manajemen laba yang akan berdampak buruk pada kualitas laba dengan menjunjung prinsip tata kelola perusahaan, transparansi, keadilan, tanggung jawab, dan akuntabilitas (National Committee on Corporate Governance, 2001).

Selain itu hasil positif tersebut juga menandakan bahwa jumlah anggota komite audit yang tinggi menandakan bahwa semakin baik pula tingkat efisiensi kegiatan pengawasan dan pengendalian terhadap aktivitas perusahaan secara keseluruhan (Khafid, 2012). Jumlah anggota komite audit pada setiap perusahaan belum tentu sama satu dengan yang lain, perbedaan jumlah tersebut harus disesuaikan dengan alokasi kebutuhan monitoring tiap perusahaan. Untuk 


\section{JURNALKU}

Volume 1 No. 4, Desember 2021

mencapai tingkat output dan outcome yang maksimal, maka jumlah komite audit sebuah perusahaan harus sesuai dengan alokasi kebutuhan yang dimiliki.

Oleh karena itu, dapat dikatakan bahwa ukuran komite audit berpengaruh positif terhadap efektivitas dan efisiensi kegiatan pengawasan dan pengendalian, sehingga akan berdampak positif pula terhadap kualitas laba yang dihasilkan.

\section{Pengaruh Manajemen Laba Riil terhadap Kualitas Laba}

\section{Pengaruh manipulasi penjualan}

Berdasarkan hasil pengujian hipotesis, dapat diketahui bahwa manajemen laba riil melalui manipulasi arus kas memiliki pengaruh negatif terhadap kualitas laba. Hasil penelitian ini menunjukan bahwa manajemen laba riil melalui manipulasi arus kas berpengaruh negatif terhadap kualitas laba. Hasil tersebut sesuai dengan hipotesis penelitian yang menyatakan manajemen laba riil berpengaruh negatif terhadap kualitas laba. Hal ini sejalan dengan hasil dari penelitian yang dilakukan oleh Cohen dan Dey (2008) yang menyatakan bahwa dalam jangka menengah begitu harga diskon dan insentif penjualan lainnya sudah tidak berlaku lagi, harga komoditas akan berangsur naik kembali ke harga normalnya, yang mengakibatkan angka penjualan akan menurun, sehingga dapat disimpulkan bahwa manipulasi penjualan hanya akan memberikan dampak positif dalam jangka pendek, namun akan berdampak buruk dalam jangka panjang.

Oleh karena berpengaruh negatif, maka semakin sering manajer perusahaan melakukan manajemen laba riil melalui manipulasi arus kas maka dampaknya akan menghasilkan kualitas laba yang rendah. Seperti yang telah disebutkan sebelumnya bahwa manajemen laba riil hanya akan memberikan dampak positif bagi manajer dalam jangka pendek, yaitu berupa naiknya angka penjualan.

Naiknya penjualan akibat manajemen laba tersebut memang terlihat baik secara akrual, namun secara arus kas hal tersebut tidak sebaik yang dibayangkan. Metode manipulasi penjualan dengan diskon dan insentif lainnya akan memiliki dampak negatif terhadap arus kas perusahaan, dimana arus kas masuk menjadi berkurang atau tidak sebanding dengan naiknya tingkat penjualan, sehingga dapat dikatakan manipulasi penjualan tersebut hanya akan berdampak positif terhadap jumlah penjualan, namun tidak terhadap arus kas masuk.

Pengaruh manipulasi beban diskresioner

Berdasarkan hasil pengujian hipotesis, dapat diketahui bahwa manajemen laba riil melalui manipulasi beban diskresioner memiliki pengaruh positif terhadap kualitas laba. Hasil tersebut tidak sesuai dengan hipotesis penelitian yang menyatakan bahwa manajemen laba riil melalui manipulasi beban diskresioner berpengaruh negatif terhadap kualitas laba.

Hubungan positif manajemen laba riil melalui manipulasi beban diskresioner dengan kualitas laba menunjukan bahwa laba akuntansi yang berkualitas tinggi merupakan hasil dari manipulasi beban diskresioner pada periode tertentu. Hal itu ditegaskan oleh Sa'diyah dan Hermanto (2017) yang menyatakan bahwa manipulasi laba dengan mengurangi beban diskresioner seperti beban iklan, beban penjualan, beban administrasi, maupun beban pengembangan dilakukan pada saat kegiatan-kegiatan tersebut dianggap tidak dapat menghasilkan revenue bagi perusahaan.

Sebagai contoh adalah pada era pandemi covid-19 dimana banyak perusahaan besar yang memutuskan untuk memangkas biaya operasionalnya karena dianggap pengeluaran operasional di masa pandemi tidak akan menghasilkan pendapatan yang signifikan. Sehingga, dengan menghapus beban diskresioner akan menghasilkan laba yang berkualitas, yaitu laba yang dapat menggambarkan kejadian di dunia nyata, bukan hanya di atas kertas saja.

Pengaruh manipulasi biaya produksi

Berdasarkan hasil pengujian hipotesis, dapat diketahui bahwa manajemen laba riil melalui manipulasi biaya produksi memiliki pengaruh positif terhadap kualitas laba. Hal 


\section{JURNALKU}

Volume 1 No. 4, Desember 2021

tersebut mengartikan bahwa kualitas laba yang tinggi dapat dicapai dengan beberapa faktor, salah satunya adalah manipulasi biaya produksi. Seperti yang telah dijelaskan sebelumnya, manipulasi biaya produksi dilakukan dengan produksi berlebih demi menghasilkan biaya produksi per unit yang rendah, tindakan tersebut akan menghasilkan harga pokok penjualan ataupun biaya penjualan yang rendah, sehingga akan meningkatkan jumlah laba yang akan dilaporkan tanpa mempengaruhi arus kas perusahaan secara signifikan (Ningsih, 2017).

Dalam kaitannya dengan konteks sampel penelitian, sebuah perusahaan dapat dinyatakan masuk ataupun bertahan dalam indeks LQ45 dinilai dari beberapa faktor, salah satunya ada kondisi keuangan perusahaan yang dinyatakan stabil oleh Bursa Efek Indonesia. Oleh karena itu, manajemen perusahaan akan berusaha semaksimal mungkin untuk menghasilkan laporan keuangan yang memiliki kinerja yang baik, salah satunya diukur dari kualitas laba yang dihasilkan, sehingga perusahaannya dapat masuk ataupun tetap bertahan dalam indeks LQ45. Untuk mencapai tujuan tersebut, maka manajer perusahaan rela melakukan cara apapun, salah satunya adalah dengan melalui manajemen laba riil. Manajemen laba riil, dalam hal ini melalui manipulasi biaya produksi, terbukti dapat memberikan pengaruh positif dalam meningkatakan kualitas laba perusahaan, dimana kualitas laba tersebut dapat dijadikan indikator penting untuk masuk ataupun bertahan di indeks LQ45.

\section{Pengaruh Kepemilikan Pemerintah terhadap Kualitas Laba}

Berdasarkan hasil pengujian hipotesis, dapat diketahui bahwa kepemilikan pemerintah memiliki pengaruh negatif terhadap kualitas laba. Hasil tersebut sesuai dengan hipotesis penelitian yang menyatakan bahwa kepemilikan pemerintah dalam suatu perusahaan akan berdampak negatif terhadap kualitas.

Pengaruh negatif tersebut dapat terjadi karena beberapa faktor, yang pertama adalah tujuan kepemilikan pemerintah. Pemerintah cenderung berorientasi terhadap jumlah laba yang dihasilkan ketimbang kualitas labanya, hal itu dikarenakan apabila jumlah laba yang dihasilkan tinggi, maka jumlah pajak dan bentuk retribusi lain yang akan dibayarkan kepada pemerintah juga akan tinggi, sehingga pemerintah sebagai pengendali utama perusahaan akan merasa diuntungkan dari kas yang dibayarkan kepada negara oleh perusahaan tersebut.

Selain itu, rendahnya kualitas laba pada BUMN di Indonesia juga disebabkan oleh rendahnya kualitas tata kelola perusahaan. Tata kelola perusahaan yang buruk akan memiliki dampak yang negatif terhadap kinerja keuangan perusahaan, sehingga kualitas laba yang dihasilkan juga akan rendah mengikuti rendahnya kualitas tata kelola di perusahaannya. Pernyataan tersebut didukung oleh penelitian yang dilakukan oleh Basuki (2020) yang menyatakan bahwa pemerintah sejauh ini belum dapat melaksanakan fungsi pengelolaan perusahaan, sehingga perusahaan yang dikuasainya (BUMN) belum mampu memberikan keuntungan finansial sesuai dengan target, tidak mampu melakukan pengembangan pangsa pasar dengan efisien, dan belum mampu mengakselerasi pertumbuhan ekonomi di daerah tempat mereka berada, dampaknya BUMN cenderung memberikan kinerja keuangan yang kurang efisien dan belum bisa berkontribusi maksimal untuk negara.

Intervensi pemerintah yang berlebihan pada BUMN juga dapat menjadi penyebab rendahnya kualitas laba dari BUMN di Indonesia. Penelitian yang dilakukan oleh Wiranata dan Nugrahanti (2013) menyatakan bahwa pemerintah dapat mengintervensi kinerja perusahaan (BUMN) demi kepentingan pemerintah semata atau bahkan demi kepentingan politik, intervensi semacam itu tentu dapat berdampak buruk terhadap kinerja perusahaan yang berakibat pada rendahnya kualitas laba yang dihasilkan. Lebih lanjut, intervensi pemerintah berupa pemberian hak monopoli juga dapat memberikan dampak negatif terhadap tata kelola dan kualitas laba yang dihasilkan. 


\section{JURNALKU}

Volume 1 No. 4, Desember 2021

\section{PENUTUP}

\section{Simpulan}

Berdasarkan hasil penelitian diatas, dapat disimpulkan bahwa dalam hal tata kelola perusahaan, kepemilikan manajerial berpengaruh positif terhadap kualitas laba. Kepemilikan manajerial dapat berguna untuk meningkatkan kualitas laba melalui manajer perusahaan yang memiliki peran ganda, baik sebagai pengelola maupun pemilik saham perusahaan, dimana peran ganda tersebut akan meningkatkan motivasi manajer untuk menghasilkan laba yang berkualitas. Kepemilikan manajerial juga merupakan salah satu solusi untuk mengatasi permasalahan konflik agensi, dengan menjadikan manajer sebagai pemilik saham, maka manajer juga akan berfokus untuk memaksimalkan kualitas laba demi naiknya harga saham yang dimiliki. Akan tetapi, dari sisi kepemilikan institusional berpengaruh negatif terhadap kualitas laba. Hal tersebut dikarenakan adanya kepemilikan institusional kurang dapat memberikan pengawasan terhadap kinerja manajemen perusahaan, sehingga menghasilkan kualitas laba yang rendah. Investor institusi juga dianggap kurang aktif berpartisipasi dalam proses pengambilan keputusan sehingga menyebabkan rendahnya kualitas laba yang dihasilkan. Selain itu, sebagian investor institusi lebih fokus terhadap tujuan jangka pendek, yaitu menaikan laba akuntansi sehingga mereka mengabaikan kualitas laba yang dihasilkan. Hal yang serupa pun terjadi pada dewan komisaris independen berpengaruh negatif terhadap kualitas laba. Hal tersebut dapat terjadi karena peran dewan komisaris independen sebagai pihak yang mengawasi kinerja manajer perusahaan dianggap kurang efektif dan efisien sehingga menghasilkan celah bagi manajer perusahan untuk melakukan manajemen laba untuk menghasilkan kualitas laba yang rendah. Selain itu, ada anggapan bahwa keberadaan dewan komisaris independen dalam sebuah perusahaan merupakan formalitas, sebatas untuk mengikuti regulasi dari OJK. Penyebab lain tidak efektifnya pengawasan dari dewan komisaris independen adalah masih tingginya peran pemegang saham dalam pengawasan terhadap manajer, sehingga independensi dari dewan komisaris independen menjadi dipertanyakan. Sedangkan untuk komite audit berpengaruh positif terhadap kualitas laba. Hal tersebut dapat terjadi karena komite audit sebagai pihak pemeriksa independen dapat menjalankan tugas pengawasannya dengan baik dalam rangka meningkatkan kualitas tata kelola perusahaan sehingga bisa menghasilkan output yang bersifat objektif yang berdampak positif terhadap kualitas laba yang dihasilkan. Selain itu, hasil tersebut dapat diartikan bahwa keberadaan komite audit telah berhasil meminimalisir dampak negatif dari konflik agensi antara manajer dengan pemilik saham sehingga berhasil meningkatkan kualitas laba yang dihasilkan.

Dalam hal manajemen laba riil dapat disimpulkan bahwa melalui manipulasi arus kas berpengaruh negatif terhadap kualitas laba. Hal tersebut dikarenakan manipulasi penjualan dilakukan oleh manajer dengan tujuan untuk meningkatkan jumlah laba ketimbang kualitas laba, selain itu manipulasi penjualan meski dapat meningkatkan laba akuntansi tapi mengakibatkan turunnya arus kas perusahaan yang akan berdampak negatif terhadap kualitas laba. Selain itu, manajemen laba riil melalui manipulasi beban diskresioner berpengaruh positif terhadap kualitas laba. Laba yang berkualitas salah satu faktornya merupakan hasil dari manipulasi beban diskresioner karena dinilai lebih menggambarkan kenyataan dibanding manipulasi penjualan. Manipulasi beban diskresioner yang dilakukan dengan mengurangi ataupun menghapuskan beban diskresioner tertentu ketika aktivitas terkait beban diskresioner tersebut tidak dapat memberikan keuntungan dan manfaat lainnya bagi perusahaan. Kemudian, manajemen laba riil melalui manipulasi biaya produksi berpengaruh positif terhadap kualitas laba. Manipulasi biaya produksi dengan cara overpoduction dipilih manajemen perusahaan karena selama ini tindakan tersebut sulit terdeteksi oleh pihak regulator, maupun pengawas lainnya seperti auditor maupun dewan komisaris. Oleh karena itu, dapat dikatakan bahwa manajemen memanfaatkan kondisi tersebut untuk melakukan manipulasi biaya produksi 


\section{JURNALKU}

Volume 1 No. 4, Desember 2021

dengan tujuan utama meningkankan kualitas laba ketimbang sekedar meningkatkan laba akuntansi saja.

Hasil penelitian ini juga menunjukan bahwa variabel kepemilikan pemerintah berpengaruh negatif terhadap kualitas laba. Selama ini perusahaan milik pemerintah dianggap memiliki model bisnis yang konvensional, bahkan beberapa BUMN di Indonesia diberi hak untuk memonopoli dan mendapat subsidi pemerintah untuk sektor usaha tertentu sehingga mengurangi persaingan yang dapat berdampak buruk terhadap kinerja perusahaan. Selain itu, pemerintah sebagai pemilik utama seringkali kurang berfokus pada kualitas laba yang dihasilkan, melainkan lebih berfokus pada jumlah laba yang dihasilkan karena semakin tinggi laba yang dihasilkan maka akan semakin tinggi pula nilai pajak dan retribusi lainnya yang akan diterima oleh pemerintah. Rendahnya kualitas laba pada BUMN juga dapat disebabkan oleh situasi trade-off yang dihadapi BUMN, dimana mereka lebih memilih untuk memaksimalkan fungsi pelayanannya ketimbang orientasi bisnisnya sehingga akan berdampak negatif terhadap kualitas laba yang dihasilkan.

\section{Saran}

Setelah melakukan penelitian terkait pengaruh tata kelola perusahaan, manajemen laba riil, dan kepemilikan pemerintah terhadap kualitas laba pada perusahaan yang terdaftar di indeks LQ-45 ini, terdapat beberapa saran yang dapat penulis berikan, yaitu untuk penelitian selanjutnya dapat menggunakan indeks lainnya yang terdapat di Bursa Efek Indonesia dikarenakan indeks tersebut terdiri atas beberapa sektor sekaligus, sehingga penelitian dapat dilakukan lebih mendalam lagi, kemudian interval waktu yang akan diteliti agar lebih panjang sehingga dapat menangkap fenomena yang terjadi, serta dapat dilakukan dengan menambah beberapa proksi lainnya terkait pengukuran tata kelola perusahaan. Bagi Otoritas Jasa Keuangan (OJK), hasil penelitian ini dapat dijadikan sebagai bahan masukan bahwa tata kelola perusahaan yang diimplementasikan oleh perusahaan di Indonesia belum mampu melakukan fungsi pengawasannya terhadap perencanaan pajak agresif. Kemudian untuk perusahaan, penelitian ini dapat digunakan sebagai bahan masukan agar dapat terus mempertahankan dan meningkatkan kualitas tata kelola perusahaannya. Selain itu, bagi investor, penelitian ini dapat dijadikan bahan pertimbangan dalam rangka pengambilan keputusan investasi.

\section{DAFTAR PUSTAKA}

Abdillah, S. Y., \& Purwanto, N. (2016). Pengaruh Good Corporate Governance Terhadap Manajemen Laba (Studi Empiris pada Perusahaan Manufaktur yang Terdaftar di Bursa Efek Indonesia Tahun 2013-2014). Jurnal Riset Mahasiswa Akuntansi Unikama, 4(1), 114.

Andjani, W. P., \& Nuswantara, D. A. (2021). Financial Distress to Income Management of SOE and POE Listed on BEI. AJABE: Journal of Accounting, Business, and Economy, $1(1), 11-20$.

Anggrainy, L., \& Priyadi, M. P. (2019). Pengaruh Struktur Modal, Pertumbuhan Laba, Kualitas Audit, dan Ukuran Perusahaan Terhadap Kualitas Laba. Jurnal Ilmu Dan Riset ..., 8(6), 2-20. http://jurnalmahasiswa.stiesia.ac.id/index.php/jira/article/view/2137

Anggreni, N. K., Putra, N. K., \& Yasa, I. N. P. (2016). Peran Corporate Governance Sebagai Pemoderasi Hubungan Tax Management dengan Kualitas Laba. Jurnal Akuntansi Dan Investasi, 17(1), 66-78. https://doi.org/10.18196/jai.2016.0045.66-78

Asri, M. (2017). The Effect of Ownership Structure on Earning Quality (Empirical Study of Manufacturing Companies Listed on Indonesia Stock Exchange). Jurnal Akuntansi Dan Keuangan.

Budianto, R. (2018). Pengaruh Good Corporate Governance Terhadap Kualitas Laba Pada Perusahaan Manufaktur yang Terdaftar di BEI pada 2015-2017. Seminar Nasionak Dan 


\section{JURNALKU}

Volume 1 No. 4, Desember 2021

Call for Paper: Manajemen, Akuntansi Dan Perbankan, 679-690. http://conferences.uinmalang.ac.id/index.php/semnasfe/article/view/770

Chan, M. C. (2016). Pengaruh Kepemilikan Pemerintah Terhadap Kualitas Laba Perusahaan Selama Periode Krisis Keuangan Global 2008. Fakultas Ekonomi Dan Bisnis Universitas Indonesia.

Cohen, D. A., \& Dey, A. (2008). Real and Accrual-based Earnings Management in the Pre- and Post- Daniel A. Cohen New York University New York, NY 10012 Aiyesha Dey Graduate School of Business University of Chicago, IL 60637 Kellog School of Management Northwestern University. The Accounting Review, 83(3), 757-787.

Darabali, P. M., \& Saitri, P. W. (2016). Analisis Faktor-Faktor Yang Mempengaruhi Kualitas Laba Pada Perusahaan Manufaktur Di Bursa Efek Indonesia Tahun 2010-2013. Jurnal Riset Akuntansi, 6(1), 46-60.

Delkhosh, M. (2017). The Effect of Accounting Conservatism and Earnings Management on Earnings Quality. International Journal of Accounting and Economics Studies, 5(2), 157162.

Gaio, C., \& Pinto, I. (2018). The role of state ownership on earnings quality: evidence across public and private European firms. Journal of Applied Accounting Research, 19(2), 312332. https://doi.org/10.1108/JAAR-07-2016-0067

HM, I., \& Sudirman, P. (2017). Pengaruh Good Corporate Governance Terhadap Kualitas Laba Pada Perusahaan Food and Beverages Yang Listing Di Bursa Efek Indonesia. Jurnal Bisnis Dan Kewirausahaan, 6(4), 422-438.

Mustika, M. (2019). Examining the Impact of Corporate Governance and Asymmetry Information towards Earning Quality (A Case Study: Manufacturing Companies in Indonesia). Advances in Economics, Business and Management Research, 73(Aicar 2018), 88-92. https://doi.org/10.2991/aicar-18.2019.20

Nanang, A. P., \& Tanusdjaja, H. (2019). Pengaruh Corporate Governance (Cg) Terhadap Kualitas Laba Dengan Manajemen Laba Sebagai Variabel Intervening Pada Perusahaan Manufaktur Yang Terdaftar Di Bei Periode 2015-2017. Jurnal Muara Ilmu Ekonomi Dan Bisnis, 3(2), 267. https://doi.org/10.24912/jmieb.v3i2.2909

Ningsih, S. (2017). Earning Management Melalui Aktivitas Riil Dan Akrual. Jurnal Akuntansi Dan Pajak, 16(01), 55-66. https://doi.org/10.29040/jap.v16i01.22

Nugroho, S. A., \& Firmansyah, A. (2018). Pengaruh Financial Distress, Real Earnings Management Dan Corporate Governance Terhadap Tax Aggressiveness. Journal of Applied Business Administration, 1(2), 163-182. https://doi.org/10.30871/jaba.v1i2.616

Oktaviani, R. N., Nur, E., \& Ratnawati, V. (2015). Pengaruh Good Corporate Governance terhadap Kualitas Laba dengan Manajemen Laba Sebagai Variabel Intervening. Jurnal SOROT, 10(1), 36-53.

Partami, N. L. N., Sinarwati, N. K., \& Darmawan, N. A. S. (2015). Pengaruh Manajemen Laba Riil Terhadap Nilai Perusahaan Dengan Corporate Governance Sebagai Variabel Pemoderasi (Studi Empiris Pada Perusahaan Manufaktur yang Terdaftar di Bursa Efek Indonesia). E-Journal Sl Ak Universitas Pendidikan Ganesha, 3(1), 1-12. https://ejournal.undiksha.ac.id/index.php/S1ak/article/view/4774

Puspitowati, N. I., \& Mulya, A. A. (2014). Pengaruh Ukuran Komite Audit, Ukuran Dewan Komisaris, Kepemilikan Manajerial, dan Kepemilikan Institusional Terhadap Kualitas Laba. Jurnal Akuntansi Dan Investasi, 3(1).

Putri, G. M., \& Fitriasari, P. (2017). Pengaruh Persistensi Laba, Good Corporate Governance dan Kualitas Audit Terhadap Kualitas Laba. Proceeding TEAM, 2, 394. https://doi.org/10.23887/team.vol2.2017.186

Roychowdhury, S. (2006). Earnings management through real activities manipulation. Journal 


\section{JURNALKU}

Volume 1 No. 4, Desember 2021

of Accounting and Economics, 42(3), 335-370. https://doi.org/10.1016/j.jacceco.2006.01.002

Sa'diyah, S., \& Hermanto, S. B. (2017). Pengaruh Manajemen Laba Akrual dan Manajemen Laba Riil Terhadap Nilai Perusahaan. Jurnal Ilmu Dan Riset Akuntansi, 6(September).

Vajriyanti, E., Putri, A. A. G. P. W., \& Dwija, I. G. A. M. A. (2019). Pengaruh Kinerja Lingkungan pada Nilai Perusahaan dengan Good Corporate Governance Sebagai Variabel Pemoderasi. E-Jurnal Akuntansi Universitas Udayana, 2183. https://doi.org/10.24843/eja.2019.v26.i03.p19

Warsini, S., \& Ichsan, T. (2013). Pengaruh Kualitas Penerapan GCG dan Konsentrasi Kepemilikan Terhadap Persistensi Laba. Prosiding Simposium Nasional Akuntansi Vokasi Ke-2 Politeknik Negeri Bali, 17-18.

Wayan, N., \& Ayu, J. (2019). Pengaruh Pertumbuhan Laba dan Mekanisme Good Corporate Governance Terhadap Kualitas Laba. Seminar Nasional INOBALI 2019, 580-589.

Zhuang, C. S. (2017). The Impact Of State Ownership On Earning Quality: State-owned Enterprises in China by Bachelor of Science. Journal of Business Finance and Accounting, May. 